\title{
Thinking Styles of Seventh Grade Students and the Effect on Misconception
}

\author{
Maya Sih Hika Pamungkas \\ Natural Science Education \\ Postgraduate of Sebelas Maret \\ University \\ Surakarta, Indonesia \\ hikapamungkas@gmail.com
}

Sulistyo Saputro

\author{
Natural Science Education \\ Postgraduate of Sebelas Maret \\ University \\ Surakarta, Indonesia \\ sulistyo68@yahoo.com
}

Sri Mulyani

\author{
Natural Science Education \\ Postgraduate of Sebelas Maret \\ University \\ Surakarta, Indonesia \\ srimulyaniuns@staff.uns.ac.id
}

\begin{abstract}
Misconception can happen in students because of several factors. The existence of misconception makes students wrong in constructing knowledge that will be continue to the next level of education. One of the factors that can lead misconception is thinking style of students. There are four types of thinking styles based on conceptual tempo. They are reflective, impulsive, quick but careful, and slow but not careful that can be identified using Matching Familiar Figure Test (MFFT). This study aims to identify thinking styles of seventh grade students. The method used in this research was survey method. Data was collected by the test in three schools with high, medium, and low grades. The results showed that there were 62 students with reflective thinking styles, there were 10 students with impulsive thinking styles, there were 2 students that quickly precise thinking styles, and there were 6 students that slowly imprecise thinking styles. This research can be used as a reference to identify student's misconceptions in certain subjects.
\end{abstract}

Keywords-reflective thinking style; impulsive thinking style; quickly precise thinking styles; slowly imprecise thinking styles; misconception

\section{INTRODUCTION}

Misconceptions or error concept is unsuitable concepts with the scientific concepts or understanding by experts. The forms of misconception are early concepts, errors, improper relationships of concepts, intuitive ideas, or naive views. The causes of misconceptions can be grouped into five causes. There are students, teachers, textbooks, context, and teaching methods. There are several causes that come from students such as early preconceptions, abilities, development stages, interests, and ways or styles of thinking. Philosophically, the occurrence of misconception in students can be explained by the philosophy of constructivism. The philosophy of constructivism states that knowledge is shaped by the students because of the contacts with the environment, challenges, and learning materials. However, because of students construct their knowledge by themselves, it is not impossible that students will be wrong so lead the misconception [1].
When referring to Piaget's theory about stages of cognitive development, students of junior high school (ages 13-15 years) are included in the formal operational level category. At this stage, junior high school students not only focus on the things they can see, but also they can think about abstract situations [2]. Misconceptions can occur when students think and build their own knowledge especially for abstract things. One of the causes of misconceptions that come from students is the way or thinking style of students. Based on thinking styles of students, there are four types of thinking styles in learning such as reflective, implusive, quickly precise, and slowly imprecise. According to Kagan [3] that thinking styles relate to the tempo or conceptual velocity is student's tendency in acting or responding, pondering, and thinking about the accuracy of an answer.

This thinking style also related to the frequency of truth and error in answering questions. Students with reflective thinking style will take longer time and more precise when take decisions, while students with impulsive thinking style will take less time but wrong in making decisions [3]. The reflective and impulsive thinking styles make a significant difference in understanding the concept of science. The average value of student's science concept understanding with reflective thinking style is greater than students with impulsive thinking style [4]. Cognitive style with conceptual tempo is significantly influence the level of error in understanding the content of the material. Students with reflective cognitive style have long time to solving the problem but they have the possibility to make mistakes, while students with impulsive cognitive style fast in solving the problem but they have high probability to make mistakes [5]. Because there are differences in understanding the concept and level of error in learning based on thinking style, it is possible that misconception will occur.

Success in education certainly cannot be separated from the success in achieving the goal of learning in school. One of the influential factors in achieving the goal of learning is student's understanding of concepts. Understanding of concept is related to the 
formation of knowledge and achievement of students. When students have misconceptions, this misconceptions certainly can effect to the understanding of concept. Students that have misconceptions will assume that the concept which they believe is true, but in reality the concept is not in same with scientific concepts. It is important to identify misconceptions and try to reduce or eliminate misconceptions. If students have misconception, it will affect to the student's knowledge. This student's knowledge will be brought continuously to the next level of education, finally affect to the learning achievement. Each student is unique who has different thinking style. It is necessary to identify student's thinking styles so the appropriate learning does not cause misconceptions.

\section{RESEARCH METHODOLOGY}

This research was conducted in three different levels of junior high school. The levels were high, medium, and low. SMP A was a high quality school, SMP B was a school with medium quality, and SMP $\mathrm{C}$ was school with low quality. Subjects in this research were students of class 7.1 at SMP A, students of class 7C at SMP B, and students of class 7.1 at SMP C. The research was conducted at even semester in the academic year of 2017/2018. This research includes qualitative research with case study method. The data in this research is score of the thinking style test which is the nominal data. Data source in this research is students. Data were collected by test. In this study, researchers used the Matching Familiar Figure Test (MFFT) which was developed by Warli [6] referring to MFFT by Jerome Kagan for classify student's thinking styles. Data were analyzed with qualitative descriptive analysis technique.

\section{RESULT AND DISCUSSION}

Intelligence is influenced by the individual's ability. But the style of thinking is not related to ability, the style of thinking is not ability. According to Zhang and Strenberg [3], the style of thinking is way to use ability. Each individual is a unique person that has characteristics. So, students have different characteristics to face up the problems and use the ability. This thinking style will affect the way of students to think when learning something.

According to Kagan [7], there are four types of thinking styles based on tempo or conceptual velocity that is the tendency of students to act or respond, reflect, and think of the accuracy of an answer. These types of thinking styles are reflective, impulsive, quickly precise, and slowly imprecise. According to Jonassen and Grabowski [3], students with reflective thinking styles are more likely to do the tasks better than students with implusive thinking styles in remembering information, reading comprehension, text interpretation, solving the problems, and making decisions. Impulsive students were tend to make mistakes more than reflective students. Students who have reflective thinking styles also more likely than impulsive students to set their own learning goal, concentrate on relevant information, and have higher achievement standards. Although majority of students with reflective thinking styles are better than students with impulsive thinking, but some children actually can make decisions and learn quickly and accurately. Reacting quickly can be a bad strategy if students give wrong answers. Some students who have reflective thinking styles will be more in depth thinking about the problem for a long time [3].

Reflective, impulsive, quickly precise, and slowly imprecise thinking styles can be identified by using a special instrument. The instrument is Matching Familiar Figure Test (MFFT) which was developed by Warli [6] referring to MFFT by Jerome Kagan. MFFT is an instrument that consist of one main image and several variations of images are almost identical to the main image. In some variations of the picture there is one picture that same with the main picture and the student is tasked to find and determine the image. According to Kagan [7], on the MFFT can used six or eight of variations picture. The type of thinking style is determined based on the time and frequency of student's error in answering the questions on MFFT [7]. MFFT is a specific instrument to determine the type of thinking style. The criteria as follows, reflective students are students with long time record and frequency of mistakes in answering the questions is little, impulsive students are students with fast times record but have many mistakes, quickly precise students are students with fast time record and have little mistakes, and slowly imprecise students are students with long time record and have many mistakes in answering the questions [6].

The criteria which was used to determine student's thinking styles is based on the median of time and frequency of mistakes [8]. Warli concluded in his research that ideal time to select the same picture with the main picture of 13 items is 14.56 minutes so the median is 7.28 minutes, while the number of possible mistakes is 13 so the median is 7 . Thus, reflective students have time criteria $>7.28$ minutes and frequency of mistakes $<7$ questions, impulsive students have time criteria $\leq 7.28$ minutes and frequency of mistakes $\geq 7$ questions, quickly precise students have time criteria $\leq 7.28$ minutes and frequency of mistakes $<7$ questions, and slowly imprecise students have time criteria $>7.28$ minutes and frequency of mistakes $\geq 7$ questions [9]. The results showed that there were 62 students with reflective thinking style, 10 students with impulsive thinking style, 2 students with quickly precise thinking style, and 6 students with slowly imprecise thinking style. Students with different thinking style may cause different misconceptions. This research 
can be used as reference to identify misconceptions based on students thinking style.

\section{CONCLUSION}

There are 62 students with reflective thinking styles, 10 students with impulsive thinking styles, 2 students with quickly precise thinking style, and 6 students with slowly imprecise thinking style. Different misconceptions may occur in students based on different thinking styles.

\section{ACKNOWLEDGMENT}

The authors say thank to the head and science teachers of SMP A, SMP B, and SMP C who have given permission and help in practice this research.

\section{REFERENCES}

[1] Suparno P. Miskonsepsi dan Perubahan Konsep dalam Pendidikan Fisika. Jakarta: PT Grasindo; 2013.

[2] Schunk D. Learning Theories an Educational Perspective (Teori-teori Pembelajaran: Perspektif Pendidikan) (6th Ed.). Terj. Eva Hamdiah, Rahmat Fajar. Yogyakarta: Pustaka Pelajar. (Original Book is Published in 2012); 2012.

[3] Santrock JW. Psikologi Pendidkan (2th Ed). Terj. Tri Wibowo B.S. Jakarta: Kencana (Original Book is Published in 2004).; 2013.

[4] Sarjana D, Margunayasa, Sumantri. Pengaruh Model
POGIL, Gaya Kognitif, dan Motivasi Berprestasi terhadap Pemahaman Konsep IPA Siswa Kelas V SD. eJournal Mimbar PGSD Universitas Pendidikan Ganesha. 2016;4(1):1-10

[5] Soemantri S. Pengaruh Gaya Kognitif Konseptual Tempo terhadap Tingkat Kesalahan Siswa. Jurnal Pendidikan dan Ilmu Pengetahuan. 2018;18(1):74-85.

[6] Warli. Kreativitas Siswa SMP yang Bergaya Kognitif Reflektif atau Impulsif dalam Memecahkan Masalah Geometri. Jurnal Pendidikan dan Pembelajaran. 2013;20(2):190-201.

[7] Haghighi M, Ghanavati M, Rahimi A. The Role of Gender Differences in the Cognitive Style of Impulsivity/Reflectivity and EFL Success. Procedia Social Behavioral Sciences. 2015;192:467-474. Available from: http://linkinghub.elsevier.com/retrieve/pii/S18770428150 35430

[8] Morovat E. Effects of Reflectivity/Impulsivity on IELTS Candidates' Band Scores in the Speaking Module of the Test. Procedia-Social Behavioral Sciences. 2014;98:1232-1239. Available from: http://linkinghub.elsevier.com/retrieve/pii/S18770428140 26299

[9] Faradillah A. The Profile of Junior High School Students' Reasoning in Solving Mathematics OpenEnded Problem According to Reflective-Impulsive Cognitive Styles. 2014, p. 113-120. 